\title{
Increasing the physical and combustion performance of Oriental beech by impregnating borates and coating liquid glass
}

\author{
Yilmaz Anil Gunbekler ${ }^{1}$ (D), Hilmi Toker ${ }^{1}$ (D), Caglar Altay ${ }^{2}$ (D), Mustafa Kucuktuvek ${ }^{3 *}$ (D) and Ergun Baysal ${ }^{1}$ (D) \\ 'Department of Wood Science and Technology, Faculty of Technology, Muğla Sıtkı Koçman University, \\ Muğla, Turkey \\ 2Department of Interior Design, Aydın Vocational School, Aydın Adnan Menderes University, Aydın, Turkey \\ ${ }^{3}$ Department of Interior Architecture and Environmental Design, Faculty of Architecture, Alanya Hamdul- \\ lah Emin Paşa University, Alanya, Antalya, Turkey \\ *mkucuktuvek@gazi.edu.tr
}

\begin{abstract}
This study was designed to investigate physical properties such as color changes after weathering and water absorption (WA) levels, and combustion performance of borates-impregnated and LG-coated Oriental beech wood. Results showed that borates impregnated and LG-coated Oriental beech wood showed positive lightness stability after weathering. The best color stabilization was obtained with LG-coated Oriental beech. Except for the $1 \mathrm{~h}$ WA period, LG did not show a water repellent effect after the water absorption test. Borates impregnation before LG-coating caused to decrease in weight loss of Oriental beech after the combustion test. Moreover, the lowest weight losses were obtained in borate impregnated Oriental beech wood.
\end{abstract}

Keywords: physical properties, combustion properties, borates, liquid glass, Oriental beech wood.

How to cite: Gunbekler, Y. A., Toker, H., Altay, C., Kucuktuvek, M., \& Baysal, E. (2021). Increasing the physical and combustion performance of Oriental beech by impregnating borates and coating liquid glass. Polímeros: Ciência e Tecnologia, 31(2), e2021022. https://doi.org/10.1590/0104-1428.20210041

\section{Introduction}

Architects and civil engineers demand high-performance wooden materials for their building designs. Besides the durability of the material, its performance against weathering plays an important role in material selection in the construction and furniture industry. On the other hand, users are expecting environmentally friendly, sustainable, aesthetic, and durable wooden materials for building proposes.

Wood material, which has been used for various purposes since the appearance of mankind in history, is one of the most important raw materials. With the rapid development of technology, the usage areas of wood material have diversified and the amount used has increased. This increase in the use of wood material causes it to be among the decreasing natural resources today ${ }^{[1]}$. It has a wide range due to its lightness, easy processing, continuous production, and superior physical and mechanical properties in various areas of use, compared to concrete, iron, aluminum, PVC, and other various building materials. It also finds uses in construction techniques, paper and cellulose, cardboard, furniture, and many other industries ${ }^{[2]}$.

The weathering process was primarily linked to sunlight irradiation and its rate was increased by higher air temperature, moisture, and other pollutants in the outdoor environment ${ }^{[3]}$. Accordingly, ultraviolet (UV) radiation and moisture were identified to be the main causes of deterioration and discoloration of wood surfaces in weather conditions ${ }^{[4,5]}$.

Since the wood material has a hygroscopic structure, it exchanges moisture with the surrounding air to adapt to the temperature and relative humidity of the environment, and if this change occurs below the fiber saturation point, it changes dimensionally. Therefore, it is not resistant to biotic and abiotic factors ${ }^{[6]}$. Traditional wood preservatives are used in the wood preservation industry to prevent the degradation of wood materials by biological organisms. Many traditional wood preservatives such as copper chromium arsenate (CCA) are prohibited due to their harmful environmental effects. However, using preservatives, environmentally friendly wood preservatives have been developed in recent years to extend the life of the wood material. Natural extracts are among the most environmentally friendly preservatives used to protect wood material. It has been seen in many scientific studies that natural plant extracts are beneficial in wood preservation ${ }^{[7]}$. Boron compounds have gained importance for wood preservatives due to their high efficiency against biological pests. Other important properties of the compounds are their ability to be easily applied by dissolving with water, their diffusion ability to wood, being cheap and easy to supply compared to other preservatives, being 
environmentally compatible and significantly increasing the fire resistance of wood material.

Various paints, varnishes, and coatings are used to improve the natural appearance of the wood and to protect it against external weather conditions ${ }^{[8]}$. Coating of the wood surface may be considered as a solution to reduce the effects of weather conditions on material deterioration and to preserve the aesthetic properties of the material exposed outdoor in different cardinal directions or varying design details ${ }^{[9]}$. If the wooden surface is not protected, it can quickly lose its aesthetic feature. Opaque coatings or transparent protective coatings are among the solutions used to protect the wood. Transparent finishes reveal the natural texture of the wood, but sunlight can damage the wood surface and cause the coating to peel off ${ }^{10]}$. Inorganic fillers, such as silicon dioxide, aluminum oxide or carbonates, silicates, and sulfates of various metals, are mainly used in wood coatings and it can be considered that liquid glass (LG) is in this group ${ }^{[11]}$.

LG is a two-component product used for waterproofing wooden surfaces requiring high chemical and physical resistance. It protects the surfaces against UV light radiation and outdoor weather conditions ${ }^{[12]}$.

The wood material is flammable and easily combustible. In addition to protecting the wood against fungus and insects, the impregnating agents also have a flame-retardant feature. The impregnation materials decompose below the decomposition temperature of the wood material and rapidly transform cellulose into charcoal and water. Thus, the formation of volatile and flammable substances at higher temperatures is prevented. Therefore, wood burns less and flames are prevented from spreading around ${ }^{[13]}$. The main components of wood appear to have quite different thermal degradation properties. It is understood that wood components decompose in different temperature ranges to release volatile substances. For example; cellulose 240-350 ${ }^{\circ} \mathrm{C}$, hemicellulose $200-260{ }^{\circ} \mathrm{C}$, lignin $280-500{ }^{\circ} \mathrm{C}^{[14]}$.

Borates are recognized as easily applicable, inexpensive, fire-retardant, and more importantly environmentally-friendly wood preservatives ${ }^{[15-17]}$. This study aimed to investigate some physical properties such as color changes after weathering and water absorption levels, and combustion performance of borates-impregnated and LG-coated Oriental beech wood, according to market expectations.

\section{Materials and Methods}

\subsection{Preparation of test specimens}

Oriental beech (Fagus orientalis L.) wood specimens were prepared with dimensions 10x100x150 mm, 20x20x20 mm, and 9x19x1016 mm (radial, tangential, and longitudinal) dimensions for color, water absorption, and combustion tests, respectively.

\subsection{Impregnation procedure}

$3 \%$ aqueous solutions of boric acid (BA), borax (BX), ammonium pentaborate(APB), and disodium octaborate tetrahydrate (DOT) were prepared to impregnate the Oriental beech wood test specimens.

The impregnation of the Oriental beech wood specimens was carried out, according to ASTM standards ${ }^{[18]}$. Test specimens were impregnated with a pre-vacuum of $760 \mathrm{~mm}$ $\mathrm{Hg}$ for 30 minutes. The specimens were then allowed to diffuse in solution at atmospheric pressure for 30 minutes. The borates retention of Oriental beech was calculated from the following Equation 1:

$$
R=\frac{G \cdot C}{V} \times 10^{3}\left(\mathrm{~kg} / \mathrm{m}^{3}\right)
$$

Where:

$\mathrm{G}=\mathrm{T}_{2}-\mathrm{T}_{1}$;

$\mathrm{T}_{2}=$ Specimen weight after impregnation $(\mathrm{kg})$;

$\mathrm{T}_{1}=$ Specimen weight before impregnation $(\mathrm{kg})$;

$\mathrm{V}=$ Specimen volume $\left(\mathrm{m}^{3}\right)$;

$\mathrm{C}=$ Solution concentration (\%).

After borates impregnation, Oriental beech wood specimens were oven-dried at $103 \pm 2{ }^{\circ} \mathrm{C}$ until the specimens reached the constant weight. Then similar to the impregnation process of borates, the wood specimens were coated with LG with a pre-vacuum of $760 \mathrm{~mm} \mathrm{Hg}$ for 30 minutes. The specimens were then allowed to diffuse in solution at atmospheric pressure for 30 minutes.

\subsection{Natural weathering}

The site where the test samples are subjected to natural weathering is within the boundaries of Mugla Sitki Kocman University. The geographical location of the university ( $37^{\circ} 09^{\prime} \mathrm{N}$ and $28^{\circ} 22^{\prime} \mathrm{E}, 670 \mathrm{~m}$ above sea level) in Mugla, Southern Aegean Region of Turkey. Weather conditions of Mugla city were taken from the directorate of meteorology. Weather conditions during the weathering process are shown in Table 1. Wood specimens, according to ASTM Standards ${ }^{[20]}$ were prepared for weathering exposure. The experimental specimens were subjected to natural weathering during the three months spanning September, October, and November 2020. The exposure rack is adjusted to the south at an angle of $45^{\circ}$. Wood specimens were prepared for natural weathering, according to ASTM Standards ${ }^{[21]}$. The color change on the surface of the test specimens after natural weathering was investigated.

\subsection{Color changes}

After the natural weathering process, the color factors $L^{*}$, $a^{*}$, and $b^{*}$ were determined. These factors are determined by the CIEL*a*b* technique and the $L^{*}$ axis signify the lightness, whereas $a^{*}$ and $b^{*}$ are the chromaticity coordinates. In this technique, the $+a *$ factors characterize the red color, and $-a *$ factors characterize the green color and the $+b *$ factors characterize the yellow color, whereas $-b^{*}$ represents the blue color. The $L^{*}$ value can differ from 100 (white) to zero (black) ${ }^{[22]}$. The colors of the specimens were measured by a colorimeter before and after weathering. The colorimeter is X-Rite SP Series Spectrophotometer, X-ride Pantone, MI, USA. The determining spot was adjusted to be equivalent 
Table 1. Weather conditions of Mugla during the weathering period ${ }^{[19]}$.

\begin{tabular}{lccr}
\hline \multicolumn{1}{c}{ Months (2020) } & September & October & November \\
\hline Average temperature $\left({ }^{\circ} \mathrm{C}\right)$ & 24.93 & 18.12 & 10.93 \\
Highest temperature $\left({ }^{\circ} \mathrm{C}\right)$ & 33.30 & 26.53 & 18.90 \\
Lowest temperature $\left({ }^{\circ} \mathrm{C}\right)$ & 18.43 & 11.33 & 5.11 \\
Humidity $(\%)$ & 49.56 & 63.17 & 63.21 \\
Average wind speed $(\mathrm{m} / \mathrm{sn})$ & 0.97 & 0.54 & 0.92 \\
Total rainfall per month $\left(\mathrm{mm}=\mathrm{kg} . \mathrm{m}^{-2}\right)$ & 3.50 & 5.93 & 6.20 \\
\hline
\end{tabular}

or not more than one-third of the distance from the center of this area to the receptor field stops.

The total color difference, $\left(\Delta \mathrm{E}^{*}\right)$ was determined for each test specimen, according to ASTM standards ${ }^{[23]}$. The color changes were calculated using Equations 2 to 5:

$$
\begin{aligned}
& \Delta a^{*}=a f^{*}-a i^{*} \\
& \Delta b^{*}=b f^{*}-b i^{*} \\
& \Delta L^{*}=L f^{*}-L i^{*} \\
& \left(\Delta E^{*}\right)=\left[\left(\Delta a^{*}\right)^{2}+\left(\Delta b^{*}\right)^{2}+\left(\Delta L^{*}\right)^{2}\right]^{1 / 2}
\end{aligned}
$$

Where $\Delta \mathrm{a}^{*}, \Delta \mathrm{b}^{*}$, and $\Delta \mathrm{L}^{*}$ represent the changes between the initial and final interval values. Five replicates were made for each treatment group. Color measurements were made in parallel to the fibers.

\subsection{Water absorption test}

For the water absorption test, Oriental beech wood specimens were kept in distilled water for 1, 8, 24, 48, 72, 96, 120,144 , and, 168 hours under $20 \pm 2{ }^{\circ} \mathrm{C}$ water temperature. At the end of each soaking period, specimens were removed from the water, dried with paper, and immediately weighed. Thus, the amount of water absorption by each specimen was calculated with the help of Equation 6.

$$
W A=\left[\left(M_{f}-M_{0 i}\right) / M_{0 i}\right] \times 100
$$

Where:

WA $=$ Water absorption (\%);

$\mathrm{M}_{\mathrm{f}}=$ Specimen weight after water absorption $(\mathrm{g})$;

$\mathrm{M}_{\mathrm{oi}}=$ Oven dry weight after impregnation ( $\mathrm{g}$ ).

\subsection{Combustion test}

Combustion test specimens were prepared in 9x19x1016 $\mathrm{mm}$ dimensions, according to ASTM standards ${ }^{[24]}$ principles. The specimens continue for a total of 10 minutes in the computer-controlled combustion testing device, with 4 minutes of flame-induced and 6 minutes of non-flame burning for each specimen. The weight loss rate as a result of the combustion was calculated with the help of the following Equation 7.

$$
L W=\frac{B C-A C}{A C} \times 100
$$

In here:

$\mathrm{LW}=$ Loss of weight $(\%)$;

$\mathrm{BC}=$ Specimen weight before combustion test $(\mathrm{g})$;

$\mathrm{AC}=$ Specimen weight after combustion test $(\mathrm{g})$;

\subsection{Statistical evaluation}

The test results were obtained as a result of the measurements and they were analyzed with SPSS statistical software program. Test results were uploaded to the computer and variance analysis was performed. Duncan test was applied at $95 \%$ statistical confidence level. The homogeneity groups (HG) of the experimental results were used for statistical evaluation. Different letters in HG indicate the difference that can be considered statistically significant.

\section{Results and Discussions}

\subsection{Color changes}

Weathering is defined as the slow decomposition and decay of materials exposed to weather factors ${ }^{[25]}$. Weathering effects can be observed depending on the type of wood or process. Abiotic factors affecting the original color and natural appearance of the wood are weathering. Ultraviolet (UV) radiation causes some changes in the wood surface. As a result, the wood turn gray in color. The fibers of the wood surface exposed to continuous radiation weaken due to two reasons. One of them is the depolymerization of lignin and the other carbohydrates in the cell wall. During the natural weathering wood materials are exposed to sunlight and as a result, lignin absorbs UV lights. This is the reason for the color changes in wooden materials. The growth of fungi may also occur on the wooden surface after weathering as well as warping, checking, and splitting ${ }^{[26,27]}$.

In order to eliminate the negative effects of outdoor weather conditions and seasonal weather changes on wood material; preservatives such as impregnation, paint, and varnish applications are applied for wood surfaces. However, the surfaces of wooden materials with top surface treatments still deteriorate over time and the upper surface appearance and strength cannot reach the desired level. In wood exposed to various biological, chemical and physical effects, it is not easy to measure the performance of surface treatment materials in outdoor conditions.

Table 2 shows $L^{*}, a^{*}$, and $b^{*}$ values of un-impregnated and non-coated (control) group, solely coated, and impregnated and coated Oriental beech specimens and also illustrates the values of change for all three-color parameters $\left(\Delta \mathrm{L}^{*}\right.$, $\Delta \mathrm{a}^{*}$, and $\left.\Delta \mathrm{b}^{*}\right)$, as well as the total color changes $\left(\Delta \mathrm{E}^{*}\right)$ 
Table 2. Color change values of Oriental beech wood specimens before and after 3 months of natural weathering.

\begin{tabular}{|c|c|c|c|c|c|c|c|c|c|}
\hline \multirow{2}{*}{ Chemicals } & \multirow{2}{*}{$\begin{array}{c}\text { Retention } \\
\left(\mathrm{Kg} / \mathbf{m}^{3}\right)\end{array}$} & \multicolumn{3}{|c|}{$\begin{array}{c}\text { Color values before natural } \\
\text { weathering }\end{array}$} & \multicolumn{3}{|c|}{$\begin{array}{c}\text { Color values after natural } \\
\text { weathering }\end{array}$} & \multicolumn{2}{|c|}{ Total color changes } \\
\hline & & $L$ & $a$ & $b$ & $\Delta L *$ & $\Delta a^{*}$ & $\Delta b^{*}$ & $\Delta E^{*}$ & $\begin{array}{l}\text { Homogeneity } \\
\text { Groups }\end{array}$ \\
\hline Control & - & 72.30 & 9.28 & 20.19 & -15.36 & -1.78 & 5.09 & 16.27 & $\mathrm{~A}$ \\
\hline LG & - & 61.46 & 8.81 & 22.01 & -2.22 & -0.40 & 4.56 & 5.08 & $\mathrm{FG}$ \\
\hline $\mathrm{BX}$ & 16.32 & 62.49 & 10.33 & 19.52 & -2.98 & -1.26 & 6.23 & 6.36 & $\mathrm{FG}$ \\
\hline $\mathrm{BX}+\mathrm{LG}$ & 17.06 & 57.95 & 8.77 & 15.47 & 8.13 & -0.64 & 9.92 & 12.84 & $\mathrm{BC}$ \\
\hline $\mathrm{BA}$ & 19.85 & 66.56 & 11.08 & 21.31 & -3.73 & -1.62 & 4.77 & 6.26 & $\mathrm{FG}$ \\
\hline $\mathrm{BA}+\mathrm{LG}$ & 20.16 & 60.71 & 8.08 & 20.50 & 3.77 & -0.95 & 2.56 & 8.15 & $\mathrm{G}$ \\
\hline DOT & 18.96 & 67.85 & 9.43 & 19.91 & -7.34 & -0.30 & 5.83 & 9.37 & $\mathrm{DE}$ \\
\hline $\mathrm{DOT}+\mathrm{LG}$ & 18.61 & 54.46 & 6.41 & 15.49 & 6.36 & -1.43 & 8.21 & 10.48 & $\mathrm{CD}$ \\
\hline $\mathrm{APB}$ & 16.53 & 63.97 & 9.66 & 18.97 & -6.13 & -0.40 & 7.77 & 7.80 & $\mathrm{EF}$ \\
\hline $\mathrm{APB}+\mathrm{LG}$ & 15.88 & 54.55 & 7.67 & 15.30 & 9.81 & -0.19 & 8.86 & 13.22 & $\mathrm{~B}$ \\
\hline
\end{tabular}

Note: LG: Liquid glass; BX: Borax; BA: Boric acid; APB: Ammonium pentaborate; DOT: Disodium octaborate tetrahydrate.

of the Oriental beech wood specimens after 3 months of weathering. The retention values of Oriental beech wood specimens impregnated with borates were varied from 15.88 to $20.16 \mathrm{~kg} . \mathrm{m}^{-3}$. Before weathering, all of the treatment groups were shown a decrease in $L^{*}$ values than that of the control group. While the $L^{*}$ value of the control group was 72.30 , it varied from 54.46 to 67.85 for the impregnated and LG-coated Oriental beech wood. The decrease in the $L^{*}$ value of Oriental beech wood specimens showed that the specimens became darker after the borates impregnation and LG-coating. These results are in good agreement with those of Ustun et al. ${ }^{[28]}$, Baysal ${ }^{[29]}$, and Simsek and Baysal ${ }^{[30]}$ studied the effects of some impregnation chemicals on the color changes of wood. The experimental results showed that borates impregnation before LG-coating caused to decrease $L^{*}$ values of Oriental beech wood specimens than that of only LG-coated Oriental beech. Moreover, $L^{*}$ values of the borates impregnated Oriental beech wood was higher than that of LG-coated Oriental beech wood. According to the experimental results, the $a^{*}$ and $b^{*}$ values of the control group were 9.28 and 20.19, while $a^{*}$ and $b^{*}$ values were 8.81 and 22.01, respectively for LG-coated Oriental beech wood. Impregnation with borates before LG-coating caused to decrease $a^{*}$ and $b^{*}$ values of Oriental beech before weathering. Except for borates impregnated and LG-coated Oriental beech wood, the negative lightness stability $\left(\Delta \mathrm{L}^{*}\right)$ values for other treatment groups occurred. Therefore, the wood surface became rougher and darker after weathering. The darkening of wood might be have been due to the degradation of lignin and other non-cellulosic polysaccharides $^{[31-33]}$.

After weathering, $\Delta \mathrm{a}^{*}$ and $\Delta \mathrm{b}^{*}$ values of the control group were found to be -1.78 and 5.09 , respectively. The control group and all treatment groups gave negative $\Delta \mathrm{a}^{*}$ and positive $\Delta \mathrm{b}^{*}$ values after weathering. Negative $\Delta \mathrm{a}^{*}$ and positive $\Delta \mathrm{b}^{*}$ values show that wood specimens' surfaces maintained greenish and yellowish tones. Impregnation with borates and LG-coating improved the color stability of Oriental beech wood compared to the untreated (control) group. While total color change $\left(\Delta \mathrm{E}^{*}\right)$ was 16.27 for the control group, it varied from 5.08 to 13.22 for all treatment groups after weathering. Color change values showed that the best color stability was observed with LG-coated Oriental beech. However, borates impregnation before LG-coating caused to increase $\Delta \mathrm{E}^{*}$ of Oriental beech. There was a statistical difference in $\Delta \mathrm{E}^{*}$ values between borates impregnated and LG-coated Oriental beech and the control group $(\mathrm{p} \leq 0.05)$.

\subsection{Water absorption}

Water absorption (WA) levels of Oriental beech wood impregnated with borates and coated with LG are given in Table 3. Especially in the first 8 hours, WA values are increasing fast and these data are consistent with the previous scientific study ${ }^{[34]}$. While the control specimens absorbed nearly $51.82 \%$ of its weight of water; the LG-coated wood absorbed $14.55 \%$ water after $1 \mathrm{~h}$. However, except for $1 \mathrm{~h}$, WA levels of LG-coated Oriental beech wood were highly increased other all WA periods.

The experimental results showed that the highest WA levels were obtained for APB impregnated Oriental beech wood for all WA periods. While the WA level of APB impregnated Oriental beech was $63.05 \%$ after $1 \mathrm{~h}$, it was $103.52 \%$ for APB impregnated Oriental beech wood after 336 h. As a result, APB impregnated Oriental beech received more than half of the total water in 1 hour of the period. Except for the $1 \mathrm{~h}$ WA period, WA levels of borate impregnated and LG-coated Oriental beech was lower than that of only LGcoated Oriental beech. Baysal et al. ${ }^{[35]}$ reported that WA of a mixture of styrene and methylmetacrilate $(1: 1 ; \mathrm{v} / \mathrm{v})$ treated wood could be reduced as much as 8 times when compared with untreated wood. Baysal et al. ${ }^{[36]}$ investigated water absorption levels of heaven wood treated with various boron compounds and coated with some vinyl monomers. Boric acid (BA), borax (BX), and a mixture of BA and BX (7:3; weight: weight) were used as boron compounds. Methyl methacrylate (MMA), styrene (ST), a mixture of ST and MMA (7.3; volume: volume), and isocyanate were used as vinyl monomers. According to the results, while the vinyl monomers used in the study, provide a significant reduction in the water absorption rate of the specimens; the monomer treatment applied on boron compounds also showed a similar effect. In our study, while LG showed a water repellent effect only $1 \mathrm{~h}$ WA period, for other WA periods it showed the same effect with borates and control group. 


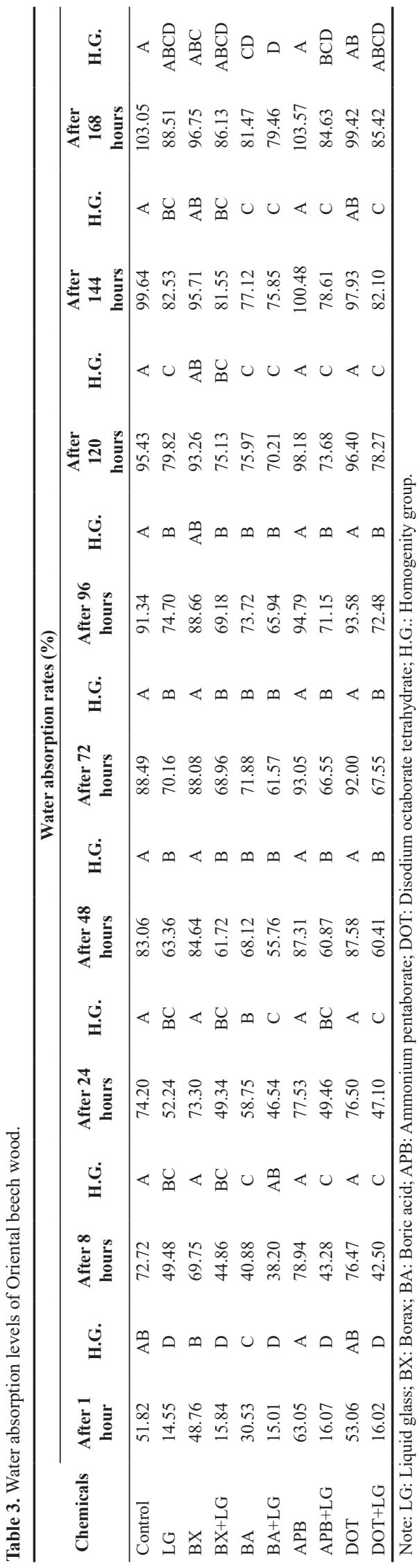




\subsection{Combustion properties}

Weight loss of Oriental beech impregnated with borates and coated with LG after combustion test is given in Table 4. While the lowest weight loss was obtained as $69.10 \%$ for DOT impregnated Oriental beech wood, the highest weight loss was measured as $83.70 \%$ for the control group. Weight loss of LG-coated Oriental beech was lower than that of the control group. But, there was no statistically significant difference in weight loss between the control group and LG-coated Oriental beech wood. Borates impregnation significantly decreased weight loss of Oriental beech compared to un-coated (control) group.

Experimental results showed that borates impregnation before LG-coating caused lower weight loss values than that of only LG-coated Oriental beech wood display the protective consequence of borates in combustion. These conclusions are consistent with the former report on the weight losses of un-treated and boron-vinyl monomer combination-treated wood ${ }^{[35]}$. Our results showed that except for BX impregnated and LG-coated Oriental beech, there were statistically significant differences in weight loss between borates impregnated and LG-coated Oriental beech and only LG-coated Oriental beech wood. Yalinkilic et al. ${ }^{[37]}$ investigated fire properties of borates and some water repellent chemicals impregnated Calabrian pine wood (Pinus brutia Ten.). They found that boron compounds increased the fire resistance of wood. Also, it was found that the increasing effect of water repellent chemicals on combustion is prevented with borates to some extent. Baysal et al. ${ }^{[36]}$ investigated combustion characteristics of heaven wood treated with various boron compounds and some vinyl monomers. Boric acid, borax, and a mixture of boric and borax (7:3; weight: weight) were used as boron compounds. Methylmethacrylate, styrene, a mixture of styrene and methylmethacrylate (7:3; volume: volume), and isocyanate were used as vinyl monomers. In terms of weight loss caused by combustion, a mixture of boric acid and borax (7:3; weight: weight) mixture gave the most favorable result with a $63 \%$ weight loss ratio. The experimental results were compatible with these researchers' findings.

Table 4. Weight loss of Oriental beech wood specimens after combustion test.

\begin{tabular}{lccc}
\hline \multirow{2}{*}{ Chemicals } & \multicolumn{3}{c}{ Weight loss (\%) } \\
\cline { 2 - 4 } & Mean & $\begin{array}{c}\text { Standard } \\
\text { deviation }\end{array}$ & $\begin{array}{c}\text { Homogeneity } \\
\text { group }\end{array}$ \\
\hline Control & 83.70 & 1.03 & $\mathrm{~A}$ \\
LG & 81.40 & 1.79 & $\mathrm{AB}$ \\
BX & 80.02 & 1.03 & $\mathrm{~B}$ \\
BX+LG & 80.93 & 3.46 & $\mathrm{AB}$ \\
BA & 71.64 & 2.05 & $\mathrm{CD}$ \\
BA+LG & 72.78 & 1.31 & $\mathrm{C}$ \\
DOT & 69.10 & 1.37 & $\mathrm{D}$ \\
DOT+LG & 69.27 & 3.74 & $\mathrm{CD}$ \\
APB & 69.57 & 3.55 & $\mathrm{CD}$ \\
APB+LG & 71.81 & 2.52 & $\mathrm{CD}$ \\
\hline
\end{tabular}

Note: LG: Liquid glass; BX: Borax; BA: Boric acid; APB: Ammonium pentaborate; DOT: Disodium octaborate tetrahydrate.

\section{Conclusions}

Some physical and combustion properties of Oriental beech wood impregnated with borates and coated with liquid glass were studied.

Before weathering, all of the treatment groups were shown a decrease in $L^{*}$ values than that of the control group. After 3 months of natural weathering test, negative lightness stability $\left(\Delta \mathrm{L}^{*}\right)$ values were occurred on the control specimens and on the specimens treated only $\mathrm{LG}$, $\mathrm{BX}, \mathrm{BA}, \mathrm{DOT}, \mathrm{APB}$. Positive lightness stability $\left(\Delta \mathrm{L}^{*}\right)$ values were obtained from the specimens treated $B X+L G$, $\mathrm{BA}+\mathrm{LG}, \mathrm{DOT}+\mathrm{LG}, \mathrm{APB}+\mathrm{LG}$. The color stability of LGcoated Oriental beech wood was higher than those of other treatment groups. The liquid glass showed a water repellency effect of only $1 \mathrm{~h}$ WA period. Except for $1 \mathrm{~h}$ WA periods, WA levels of borates impregnated and LG-coated Oriental beech was lower than only LG-coated Oriental beech. Weight loss was the highest for the control group after the combustion test. Borates impregnation before LG-coating caused to decrease in weight loss of Oriental beech after combustion test. Borates impregnated Oriental beech gave the best results in terms of combustion properties.

Boron compounds have a low environmental impact compared to other conventional impregnation materials and cause acute toxicity in very small amounts. In addition, it is colorless and odorless, has no corrosive properties, and is resistant to fire. $L G$ possesses excellent water resistance and can be produced as a transparent or color product that is resistant to atmospheric conditions. LG has high performance against UV light radiation and outdoor weather conditions.

As a result; It may be beneficial to use liquid glass and boron compounds for waterproofing the wood material and to increase the resistance of the wood material against UV light, radiation, and outdoor weather conditions, and to increase its combustion performance.

\section{Acknowledgements}

This study was taken from some of the data of the master's thesis of Yilmaz Anil Gunbekler, who is continuing his master's degree at Mugla S1tk1 Kocman University Institute of Science. This study also was supported by a scientific project of the Scientific Research Unit of Mugla S1tk1 Kocman University. The project number is $20 / 099 / 02 / 2$.

\section{References}

1. Kartal, S. N., \& Imamura, Y. (2004). The use of boron as wood preservative systems for wood and wood-based composites. In II International Boron Symposium (pp. 333-338). Eskişehir, Turkey: Solid State Sciences.

2. Baysal, E. (2011). Combustion properties of Calabrian pine impregnated with aqueous solutions of commercial fertiliziers. African Journal of Biotechnology, 10(82), 19255-19260. http:// dx.doi.org/10.5897/AJB11.3054.

3. Pandey, K. K. (2005). Study of the effect of photo-irradiation on the surface chemistry of wood. Polymer Degradation \& Stability, 90(1), 9-20. http://dx.doi.org/10.1016/j. polymdegradstab.2005.02.009. 
4. Huang, X., Kocaefe, D., Kocaefe, Y., Boluk, Y., \& Pichette, A. (2012). A spectrocolorimetric and chemical study on color modification of thermally modified wood during artificial weathering. Applied Surface Science, 258(14), 5360-5369. http://dx.doi.org/10.1016/j.apsusc.2012.02.005.

5. Berdahl, P., Akbari, H., Levinson, R., \& Miller, W. A. (2008). Weathering of roofing materials-an overview. Construction \& Building Materials, 22(4), 423-433. http://dx.doi.org/10.1016/j. conbuildmat.2006.10.015.

6. Ors, Y., \& Keskin, H. (2008). Ağaç malzeme teknolojisi. Ankara, Turkey: Gazi University Publishing.

7. Salem, M. Z. M., Zidan, Y. E., El Hadidi, N. M. N., Mansour, M. M. A., \& Abo Elgat, W. A. A. (2016). Evaluation of usage three natural extracts applied to three commercial wood species against five common molds. International Biodeterioration \& Biodegradation, 110, 206-226. http://dx.doi.org/10.1016/j. ibiod.2016.03.028.

8. Cristea, M. V., Riedl, B., \& Blanchet, P. (2010). Enhancing the performance of exterior waterborne coatings for wood by inorganic nanosized UV absorbers. Progress in Organic Coatings, 69(4), 432-441. http://dx.doi.org/10.1016/j. porgcoat.2010.08.006.

9. Herrera, R., Sandak, J., Robles, E., Krystofiak, T., \& Labidi, J. (2018). Weathering resistance of thermally modified wood finished with coatings of diverse formulations. Progress in Organic Coatings, 119, 145-154. http://dx.doi.org/10.1016/j. porgcoat.2018.02.015.

10. Pandey, K. K., \& Pitman, A. J. (2002). Weathering characteristics of modified rubberwood (Hevea brasiliensis). Journal of Applied Polymer Science, 85(3), 622-631. http://dx.doi.org/10.1002/ app.10667.

11. Prieto, J., \& Kiene, J. (2007). Holzbeschichtung: chemie und praxis. Hannover: Vincentz Network.

12. Isonem. (2019, 3 february). Retrieved in 2021, May 15, from http://www.isonem.com

13. LeVan, S. L., \& Winandy, J. E. (1990). Effects of fire retardant treatments on wood strength: a review. Wood and Fiber Science, 22(1), 113-131. Retrieved in 2021, May 15, from https://wfs. swst.org/index.php/wfs/article/view/2074

14. Drysdale, D. (1996). An introduction to fire dynamics. USA: John Wiley \& Sons.

15. Thevenon, M. F., Pizzi, A., \& Haluk, J. P. (1997). Non-toxic albumin and soja protein borates as ground-contact wood preservatives. Holz als Roh- und Werkstoff, 55(5), 293-296. http://dx.doi.org/10.1007/s001070050231.

16. Yalinkilic, M. K., Yusuf, S., Yimura, T., Takahashi, M., \& Tsunoda, K. (1996). Effect of vapor phase formalization of boric acid treated wood on boron leachability and biological resistance. In 3 rd Pacific Rim bio-Based Composite Symposium (pp. 544-551). Kyoto, Japan: BIOCOMP.

17. Arthur, L. T., \& Quill, K. (1992). Commercial flame retardant applications of boron compounds. In Flame Retardants 92 Conference (pp. 233-237). Westminster, London: Elsevier Applied Science.

18. American Society for Testing and Materials-ASTM. (2007). ASTM 1413-07e1: standard test method for wood preservatives by laboratory soil-block cultures. West Conshohocken: ASTM International.

19. Turkish State Meteorological Service. (2020). Retrieved in 2021, May 15, from http://www.mgm.gov.tr

20. American Society for Testing and Materials-ASTM. (2013). ASTM D7787/D7787M-13: standard practice for selecting wood substrates for weathering evaluations of architectural coatings. West Conshohocken: ASTM International.
21. American Society for Testing and Materials - ASTM. (2013). ASTM G7/G7M-13: standard practice for atmospheric environmental exposure testing of nonmetallic materials. West Conshohocken: ASTM International.

22. Zhang, X. (2003). Photo-resistance of alkyl ammonium compound treated wood (Master thesis). The University of British Colombia, Vancouver, Canada. Retrieved in 2021, May 15, from https://open.library.ubc.ca/cIRcle/collections/ ubctheses/831/items/1.0075034

23. American Society for Testing and Materials - ASTM. (1964). ASTM D1536-58 T: tentativemethod of test color difference using the color master differential colourimeter. West Conshohocken: ASTM International.

24. American Society for Testing and Materials - ASTM (2007). ASTM-E 69: standard test methods for combustible properties of treated wood by the fire apparatus. West Conshohocken: ASTM International.

25. Sandak, J., Sandak, A., \& Riggio, M. (2015). Characterization and monitoring of surface weathering on exposed timber structures with a multi-sensor approach. International Journal of Architectural Heritage, 9(6), 674-688. http://dx.doi.org/10. 1080/15583058.2015.1041190.

26. Mohebby, B., \& Saei, A. M. (2015). Effects of geographical directions and climatological parameters on natural weathering of fir wood. Construction \& Building Materials, 94, 684-690. http://dx.doi.org/10.1016/j.conbuildmat.2015.07.049.

27. Ghosh, S. C., Militz, H., \& Mai, C. (2009). Natural weathering of Scots pine (Pinus sylvestris L.) boards modified with functionalised commercial silicone emulsions. BioResources, 4, 659-673. http://dx.doi.org/10.15376/BIORES.4.2.659-673.

28. Ustun, S., Baysal, E., Turkoglu, T., Toker, H., Sacli, C., \& Peker, H. (2016). Surface characteristics of Scots pine treated with chemicals containing some copper compounds after weathering. Wood Research, 61(6), 903-914., Retrieved in 2021, May 15, from http://www.woodresearch.sk/wr/201606/06.pdf

29. Baysal, E. (2012). Surface characteristics of CCA treated Scots pine after accelerated weathering. Wood Research, 57(3), 375-382. Retrieved in 2021, May 15, from http://www. woodresearch.sk/wr/201203/04.pdf

30. Simsek, H., \& Baysal, E. (2012). An investigation on colour and gloss changes of wood impregnated with borates. Wood Research, 57(2), 271-277. Retrieved in 2021, May 15, from http://www.woodresearch.sk/wr/201202/09.pdf

31. Hon, D. N.-S., \& Chang, S.-T. (1985). Photoprotection of wood surfaces by wood-ion complexes. Wood and Fiber Science, 17(1), 92-100. Retrieved in 2021, May 15, from https://wfs. swst.org/index.php/wfs/article/view/325

32. Grelier, S., Castellan, A., \& Kamdem, D. P. (2000). Photoprotection of copper-amine-treated pine. Wood and Fiber Science, 32(2), 196-202. Retrieved in 2021, May 15, from https://wfs.swst. org/index.php/wfs/article/view/240

33. Petric, M., Kricej, B., Humar, M., Pavlic, M., \& Tomazic, M. (2004). Patination of cherrywood and spruce wood with ethanolamine and surface finishes. Surface Coatings International. Part B, Coatings Transactions, 87(3), 195-201. http://dx.doi. org/10.1007/BF02699635.

34. Hafizoglu, H., Yalinkilic, M. K., Yildiz, U. C., Baysal, E., Peker, H., \& Demirci, Z. (1994). Türkiye bor kaynaklarının odun koruma (Emprenye) endüstrisinde değerlendirilme imkânları, TOAG-875 (Tübitak Project). Trabzon, Turkey: Karadeniz Teknik Üniversitesi.

35. Baysal, E., Yalinkilic, M. K., Altinok, M., Sonmez, A., Peker, H., \& Colak, M. (2007). Some physical, biological, mechanical, and fire properties of wood polymer composite (WPC) pretreated with boric acid and borax mixture. Construction \& Building 
Materials, 21(9), 1879-1885. http://dx.doi.org/10.1016/j. conbuildmat.2006.05.026.

36. Baysal, E., Peker, H., \& Colak, M. (2004). Borlu bileşikler ve su itici maddelerin cennet ağacı odununun fiziksel özellikleri üzerine etkileri. Erciyes University Journal of Institute Science and Technology, 20(1-2), 55-65. Retrieved in 2021, May 15, from https://dergipark.org.tr/tr/pub/erciyesfen/ issue $/ 25602 / 270163$
37. Yalinkilic, M. K., Baysal, E., \& Demirci, Z. (1997). Bazı borlu bileşiklerin ve su itici maddelerinin Kızılçam odununun yanma özellikleri üzerine etkileri. Turkish Journal of Agriculture and Forestry, 21, 423-431.

Received: May 15, 2021 Revised: Aug. 21, 2021 Accepted: Aug. 23, 2021 